\title{
Application of Deep Learning Convolution Neural Network Method on KRSBI Humanoid R-SCUAD Robot \\ Penerapan Metode Deep Learning Convolution Neural Network pada Robot KRSBI Humanoid R-SCUAD
}

\author{
Syahid Al Irfan ${ }^{1}$, Nuryono Satya Widodo ${ }^{2}$ \\ ${ }^{1}$ Mahasiswa Program Studi Teknik Elektro, Universitas Ahmad Dahlan, Indonesia \\ ${ }^{2}$ Dosen Program Studi Teknik Elektro, Universitas Ahmad Dahlan, Indonesia
}

\section{INFORMASI ARTIKEL}

\section{Riwayat Artikel:}

Dikirimkan 20 Agustus 2019, Direvisi 14 Mei 2020,

Diterima 14 Mei 2020.

\section{Kata Kunci: \\ Deep Learning, \\ CNN, \\ Robot Humanoid, \\ Ternsor Flow.}

\section{Penulis Korespondensi:}

Nuryono Satya Widodo, Universitas Ahmad Dahlan, Yogyakarta, Indonesia. Surel/Email: nuryono.sw@ee.uad.ac.id

\section{ABSTRACT / ABSTRAK}

In a soccer game the ability of humanoid robots that one needs to have is to see the ball object in real time. Development of the ability of humanoid robots to see the ball has been developed but the level of accuracy of object recognition and adaptation during matches still needs to be improved. The architecture designed in this study is Convolutional Neural Network or CNN which is designed to have 6 hidden layers with implementation of the robot program using the Tensorflow library. The pictures taken are used in the training process to have 9 types of images based on where the pictures were taken. Each type of image is divided into 2 classes, namely 2000 images for ball object classes and 2000 images for non-ball object classes. The test is done in real time using a white ball on green grass. From the architectural design and white ball detection test results obtained a success rate of $67 \%$, five of the nine models managed to recognize the ball. The model can recognize objects with an image processing speed of a maximum of 13 FPS.

Dalam pertandingan sepak bola kemampuan robot humanoid yang perlu dimiliki salah satunya adalah melihat objek bola secara real time. Pengembangan kemampuan robot humanoid untuk melihat bola telah dikembangkan tetapi tingkat akurasi pengenalan objek dan adaptasi saat pertandingan masih perlu ditingkatkan. Arsitektur yang dirancang pada penelitian ini yaitu Convolutional Neural Network atau CNN yang dirancang memiliki 6 hidden layer dengan implementasi pada program robot menggunakan library Tensorflow. Gambar yang diambil digunakan dalam proses training memiliki 9 jenis gambar berdasarkan tempat pengambilan gambar. Tiap jenis gambar terbagi menjadi 2 class yaitu 2000 gambar untuk class objek bola dan 2000 gambar untuk class objek bukan bola. Pengujian dilakukan secara real time dengan menggunakan bola berwarna putih di atas rumput hijau. Dari perancangan arsitektur dan hasil pengujian pendeteksian bola putih didapatkan persentase keberhasilan $67 \%$ yaitu lima dari sembilan model berhasil mengenali bola. Model dapat mengenali objek dengan kecepatan pengolahan gambar adalah maksimal 13 FPS.

This work is licensed under a Creative Commons Attribution-Share Alike 4.0

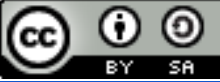

\section{Sitasi Dokumen ini:}

S. A. Irfan, N. S. Widodo, “Application of Deep Learning Convolution Neural Network Method on KRSBI Humanoid R-SCUAD Robot,” Buletin Ilmiah Sarjana Teknik Elektro, vol. 2, no. 1, pp. 40-50, 2020. DOI: 10.12928/biste.v2i1.985 


\section{PENDAHULUAN}

Kontes Robot Sepak Bola Indonesia (KRSBI) adalah salah satu program kreativitas mahasiswa di bawah kegiatan induk Kontes Robot Indonesia (KRI) yang pada tahun 2018 memasuki tahun ke-18 sejak pertama kali diadakan. Sesuai dengan Road Map kegiatan ini dinilai sangat strategis untuk dapat menjadi salah satu keunggulan objek penelitian dan edukasi rekayasa robotika tingkat dunia dengan kiblat langsung kepada komunitas yang sama di seluruh dunia.

Pada tahun 2012 Tim R-SCUAD mulai mengikuti kontes Kontes Robot Cerdas Indonesia (KRCI) divisi robot pemain sepak bola atau biasa disebut divisi Humanoid Soccer. Dengan mengadopsi platform Dynamic Anthropomorphic Robot with Intelligence - Open Platform (DARwIn-OP) sebagai dasar perancangan robot sepak bola, tim R-SCUAD telah membangun beberapa robot yang memiliki kemampuan untuk bermain bola seperti melihat, mengejar dan menendang bola serta melakukan gerakan-gerakan khusus seperti bangun dari keadaan terbaring. Meskipun begitu kemampuan yang dimiliki robot R-SCUAD masih jauh dari harapan akhir pengembangan robot sepak bola yaitu membangun robot yang dapat bermain sepak bola layaknya manusia.

Teknologi pada robot R-SCUAD dilihat dari segi kemampuan untuk bermain sepak bola seperti melihat bola, berjalan di atas rumput dan menendang bola masih banyak yang harus ditingkatkan baik dari segi software maupun hardware. Dari segi software, sampai sejauh ini beberapa teknologi yang digunakan pada robot RSCUAD masih tergantung pada platform DARwIn-OP sehingga teknologi yang digunakan seperti pengolahan citra, sistem keseimbangan dan teknologi lainnya yang ada pada robot juga menjadi lebih terbatas.

Salah satu hal yang perlu dibenahi adalah sistem visi pada robot. Pada sistem visi robot hal-hal yang perlu dibenahi seperti persentase robot untuk dapat melihat bola putih secara realtime masih belum maksimal, jarak robot untuk melihat bola putih secara efektif masih kurang dari 2 meter dan juga framerate yang didapat masih kurang dari 20 FPS.

Sejak KRI tahun 2016 peraturan untuk pertandingan kontes tersebut khususnya pada KRSBI H memiliki beberapa perubahan salah satunya bola yang digunakan untuk pertandingan adalah bola dengan warna dasar putih yang pada tahun-tahun sebelumnya berwarna Jingga. Perubahan peraturan tersebut berpengaruh pada sistem visi pada robot R-SCUAD yang digunakan sebelumnya menggunakan algoritme untuk mencari bola berwarna Jingga. Penelitian sebelumnya untuk menemukan bola yang digunakan pada robot R-SCUAD telah dilakukan oleh Tsani (2015) yang mana menggunakan pustaka OpenCV dan metode yang terdapat di dalamnya yaitu metode Hough Circle untuk menemukan bola berwarna Jingga. Penelitian tersebut memiliki persentase keberhasilan sebesar 76,25\% tetapi hal tersebut hanya berlaku jika bola yang dicari adalah bola berwarna Jingga sehingga pengaturan yang dilakukan akan berbeda dengan yang telah diteliti.

\section{METODE PENELITIAN}

Pada penelitian ini akan digunakan robot Humanoid R-SCUAD yang memiliki konfigurasi dan platform yaitu platform DARwIn-OP2. Robot R-SCUAD ini dibangun untuk diikutkan pada lomba KRSBI Humanoid (Kontes Robot Sepak Bola Indonesia Humanoid) yang diselenggarakan oleh DIKTI (Direktorat Jendral Pendidikan Tinggi) sehingga fungsi utama robot ini adalah untuk dapat bermain sepak bola sesuai dengan peraturan yang telah ditetapkan seperti melihat bola, berjalan mengejar bola dan menendang bola. Gambar dari desain kerangka robot R-SCUAD dengan platform lama dapat dilihat pada Gambar 1.

Pada Gambar 3.2 ditunjukkan bagian-bagian motor servo robot dengan nomor 1 sampai dengan 20. Robot R-SCUAD memiliki 20 servo penggerak yang berfungsi sebagai sendi seperti manusia pada umumnya. Semua servo tersebut diberikan nomor atau dapat disebut ID yang berfungsi sebagai pemberian identitas agar saat pengiriman data dari main controler dapat diterima sesuai perintah yang dikirimkan. Pemberian nomor tersebut dapat dilakukan secara manual dengan bantuan software Roboplus Manager. Pemberian ID dan fungsinya tiap servo tersebut dapat dilihat pada Tabel 1.

Tabel 1 Pengalamatan ID Servo R-SCUAD

\begin{tabular}{clcl}
\hline Nomor Servo & \multicolumn{1}{c}{ Letak/ posisi } & Nomor Servo & \multicolumn{1}{c}{ Letak/ posisi } \\
\hline 1 & Pundak kanan & 11 & Paha depan kanan \\
\hline 2 & Pundak kiri & 12 & Paha depan kiri \\
\hline 3 & Lengan tangan kanan & 13 & Lutut kanan \\
\hline 4 & Lengan tangan kiri & 14 & Lutut kiri \\
\hline 5 & Pinggang kanan & 15 & Engkel depan kanan \\
\hline 6 & Pinggang kiri & 16 & Engkel depan kiri \\
\hline 7 & Siku kanan & 17 & Engkel belakang kanan \\
\hline 8 & Siku kiri & 18 & Engkel belakang kiri \\
\hline 9 & Paha belakang kanan & 19 & Leher \\
\hline 10 & Paha belakang kiri & 20 & Kepala \\
\hline
\end{tabular}




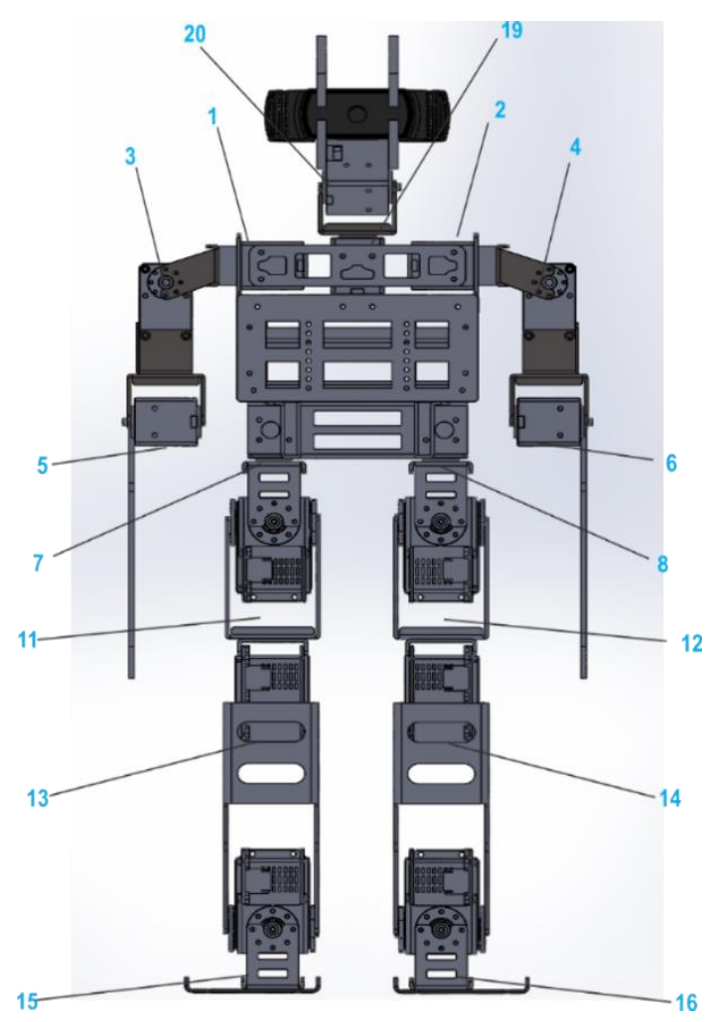

(a)

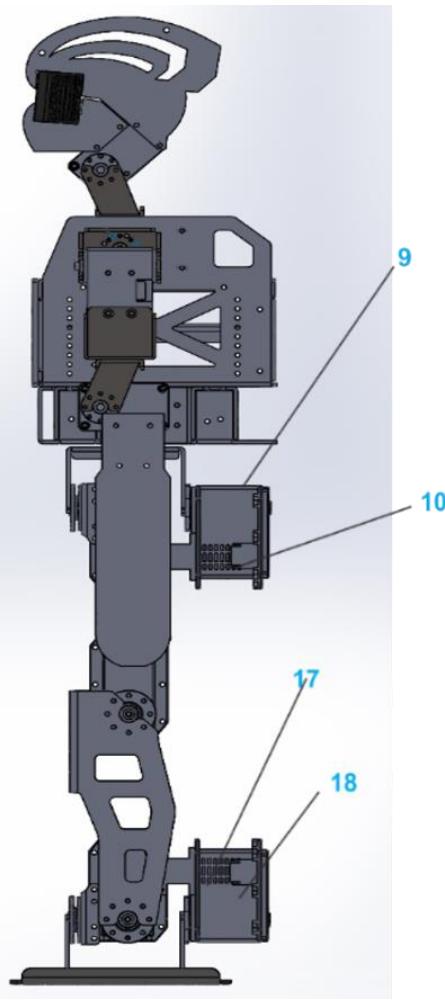

(b)

Gambar 1. Desain Robot

Pada penelitian ini secara umum sistem kerja pada robot R-SCUAD dapat dilihat pada diagram blok yang pada Gambar 2 dengan penjelasan sebagai berikut. Terdapat beberapa komponen blok seperti intel NUC, kamera, WiFi, OpenCR, Server Wasit dan servo 1 sampai servo 20. Fungsi intel NUC pada sistem adalah sebagai main contrloer yaitu pemberi perintah secara umum kepada robot dan juga sebagai pengolah informasi penting seperti pengolahan Citra dan juga pengolahan perintah wasit dan di tempat ini juga program dasar robot diolah. Selanjutnya terdapat OpenCR yang mana berfungsi sebagai sub-controler yang berbeda dengan main controller dan hanya menerima dan mengirim perintah dari main contrloer ke servo yang ditentukan. Pada sub-contrloer juga terdapat sensor gyroscope dan accelerometer yaitu sensor gravitasi dan sensor kecepatan dan digunakan sebagai acuan sistem keseimbangan pada robot. Lalu pada diagram terdapat juga kamera sebagai input untuk pengolahan Citra dan modul WiFi untuk menerima perintah secara nirkabel dari server wasit.

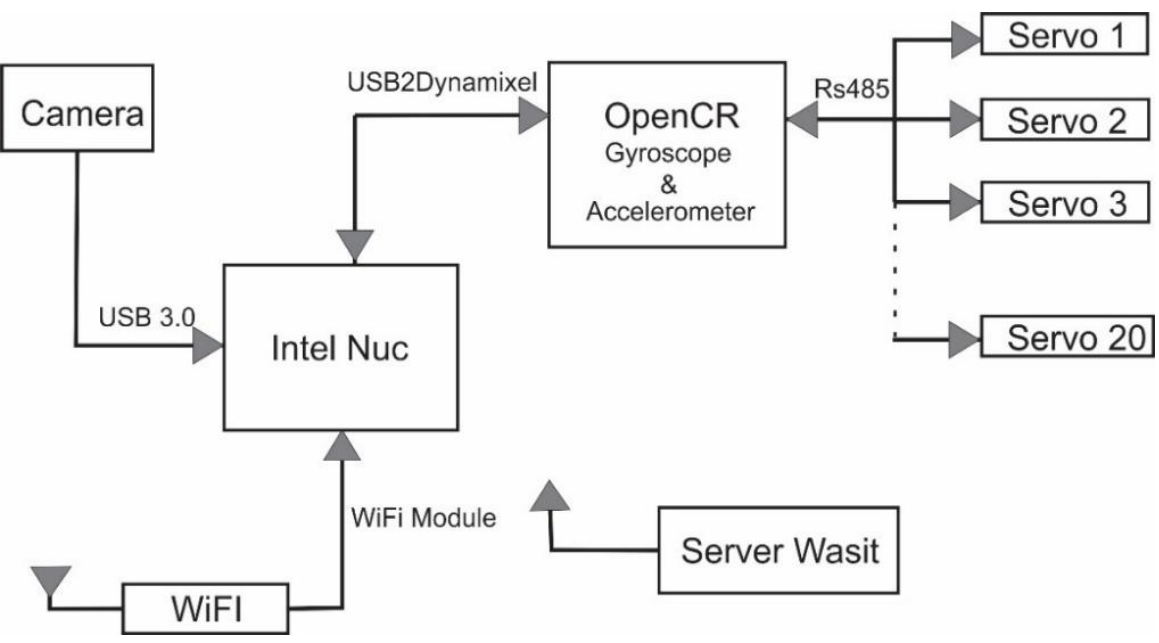

Gambar 2. Diagram blok sistem pada robot R-SCUAD 


\section{Penerapan Deep Learning pada Pengolahan Citra}

Sistem pengolahan citra pada penelitian ini dirancang dengan menerapkan metode deep learning dengan algoritma Convolutional neural networks dengan penggunaan beberapa layer dan dua jenis fungsi aktivasi. Sebelum dilakukan pengujian data, data yang didapat harus dilakukan pelatihan terlebih dahulu. Sistem pelatihan akan dirancang agar saat sistem memulai program maka Citra yang didapat akan diperkecil resolusi gambar sampai 128 x 128 setelah itu hasil dari gambar tersebut dilakukan operasi Convolution Neural Network untuk memprediksi daerah yang dicari lalu diterapkan pada seluruh area gambar untuk meningkatkan kinerja pendeteksian. Sistem pelatihan yang digunakan menggunakan enam layer dengan empat hidden layer, satu sebagai input dan satu sebagai output. Dari keempat hidden layer tersebut empat menggunakan fungsi aktivasi ReLu dan layer terakhir output menggunakan fungsi aktivasi Sigmoid. Bentuk grafik dari fungsi aktivasi sigmoid dan ReLu dapat dilihat dari Gambar 3.

Sigmoid

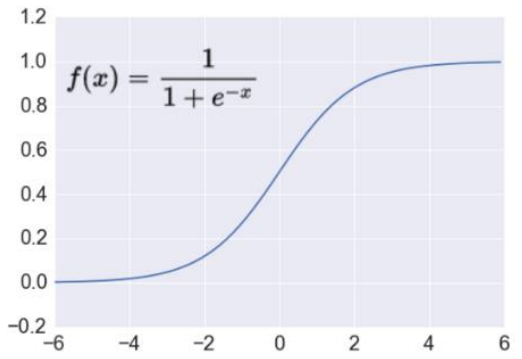

ReLU

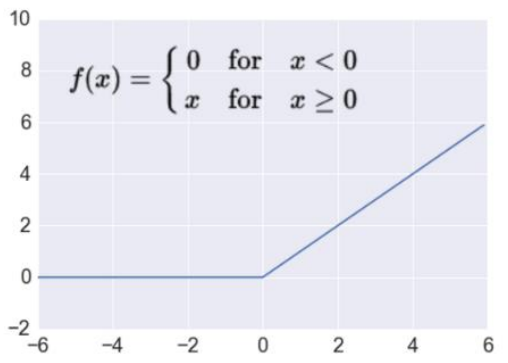

Gambar 3. Bentuk fungsi aktivasi

Proses pengambilan data untuk diujikan dilakukan dengan mengambil citra bola sebagai objek yang akan dideteksi sebanyak 2000 data citra untuk masukan sebagai data pelatihan dan 2000 data citra sebagai objek validasi. Perangkat yang digunakan untuk pengambilan data adalah kamera webcam Logitech c922 dan sebuah PC. Arsitektur yang disusun pada program sistem pelatihan pengolahan citra tersebut dapat dilihat pada Gambar 4.

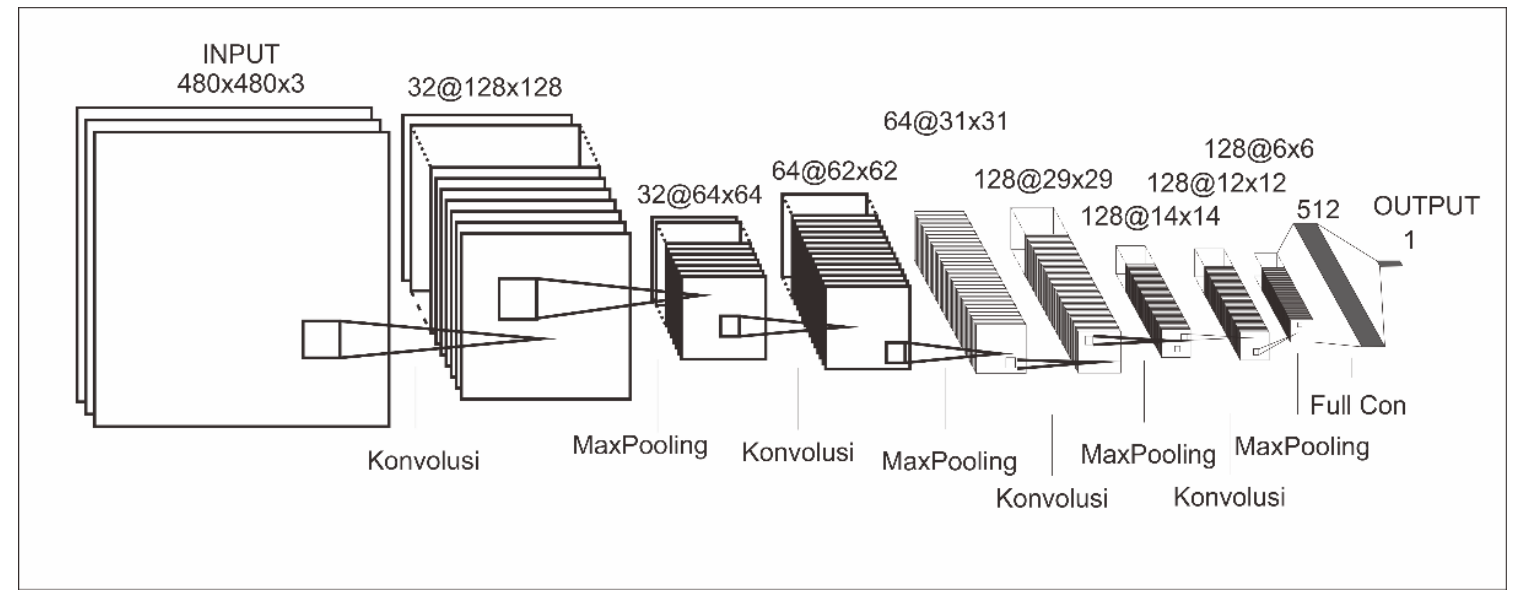

Gambar 4 Arsitektur CNN yang dibangun

Untuk diagram alir sistem pelatihan pengolahan citra yang dirancang dapat dilihat pada Gambar 5. Teknik pengambilan data dilakukan dengan menjalankan program pengolahan citra yang dirancang menggunakan bahasa Python dan pustaka OpenCV dimana program akan terus berjalan dan menangkap Citra video kemudian menyimpan data citra tiap frame ke dalam bentuk file sampai nilai penghitung data citra mencapai batasnya.

\section{Pengujian Sistem}

Objek yang dideteksi pada penelitian ini adalah bola dengan bola berwarna putih dan bercorak hitam. Contoh gambar dari objek yang akan dideteksi yang dapat dilihat pada Gambar 6. Pengaturan yang dilakukan pada penggunaan pustaka Keras untuk pelatihan data dibuat sama untuk setiap pelatihannya di antaranya adalah a. Model pelatihan 
Model pelatihan yang digunakan pada penelitian ini menggunakan model Sequensial dari pustaka Keras. Model ini dipilih karena pada model ini layer yang akan digunakan dapat dirancang sesuai dengan kebutuhan.

b. Layers

Layers yang digunakan pada penelitian ini berjumlah 6 hidden layer dengan 4 jenis layer conv2D dengan fungsi aktivasi ReLu dan dua lainnya berjenis Dense dimana satu layer menggunakan fungsi aktivasi dan yang terakhir menggunakan fungsi aktivasi Sigmoid.

c. Pengaturan fungsi compile

Saat dilakukan compile Optimizer yang digunakan adalah RMSprop dengan learning rate 0.0003, loss function yang digunakan adalah binary crossentropy

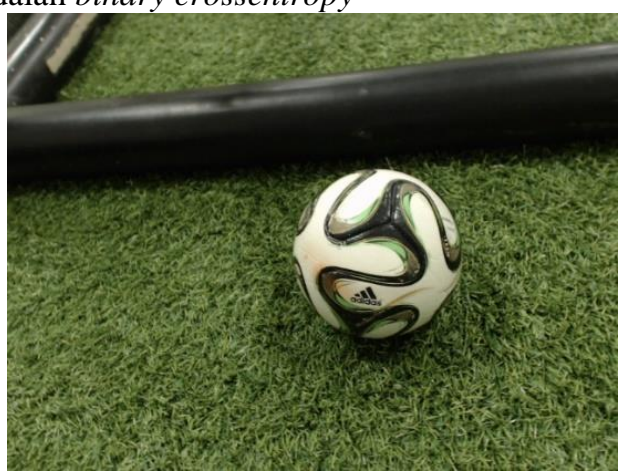

Gambar 6 Gambar Bola yang akan dideteksi

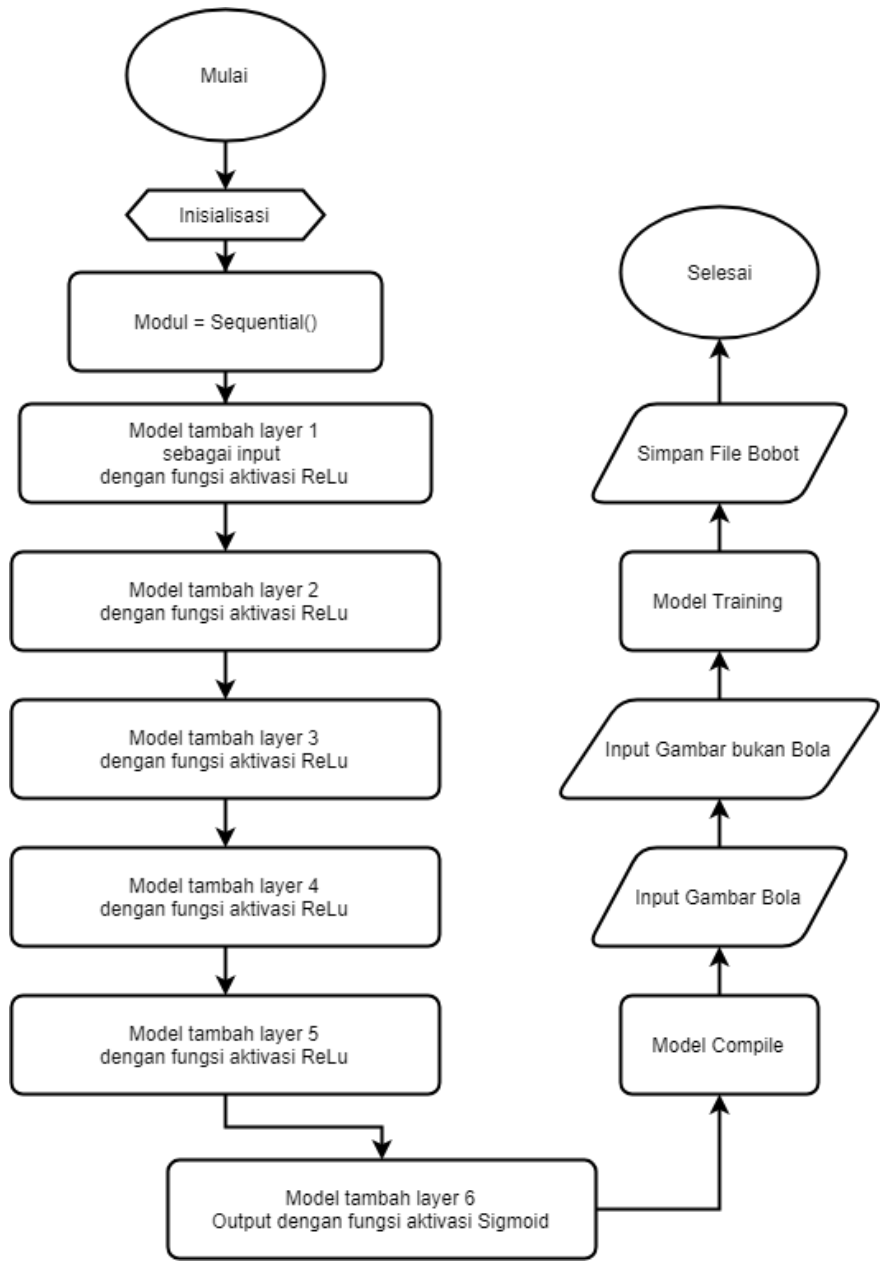

Gambar 5 Diagram alir sistem training robot 
d. Data generator

Untuk data pelatihan dataset yang digunakan adalah data generator dengan data untuk pelatihan dan validasi yang sudah disiapkan dalam bentuk folder

e. $\quad$ Training data

Pelatihan data dilakukan dengan ketentuan epoch sampai dengan 15, step per epoch 5 dan step validasi adalah 7.

Setelah pendeteksian objek selesai dirancang selanjutnya sistem akan diuji dengan beberapa objek yang berhubungan seperti untuk pendeteksian objek bola. Dikarenakan objek bola memiliki warna yang menyerupai beberapa benda di lapangan seperti garis lapang dan gawang, pengujian untuk pendeteksian bola akan dilakukan dengan menaruh objek bola di atas garis lapang dengan diujikan dari beberapa sudut penglihatan. Saat berada di lapangan posisi jika dilihat dari posisi robot saat di lapangan latar belakang gawang tidak menentu dan saat kamera ditujukan ke arah gawang pencahayaan yang didapat terkadang berbeda sehingga untuk pengujian ini akan dilakukan dengan mengganti latar belakang objek dengan latar belakang yang diperkirakan akan menjadi gangguan saat pertandingan dilaksanakan seperti beberapa objek putih seperti kertas, bendera dan yang lainnya. Untuk diagram alirnya dapat dilihat pada Gambar 7.

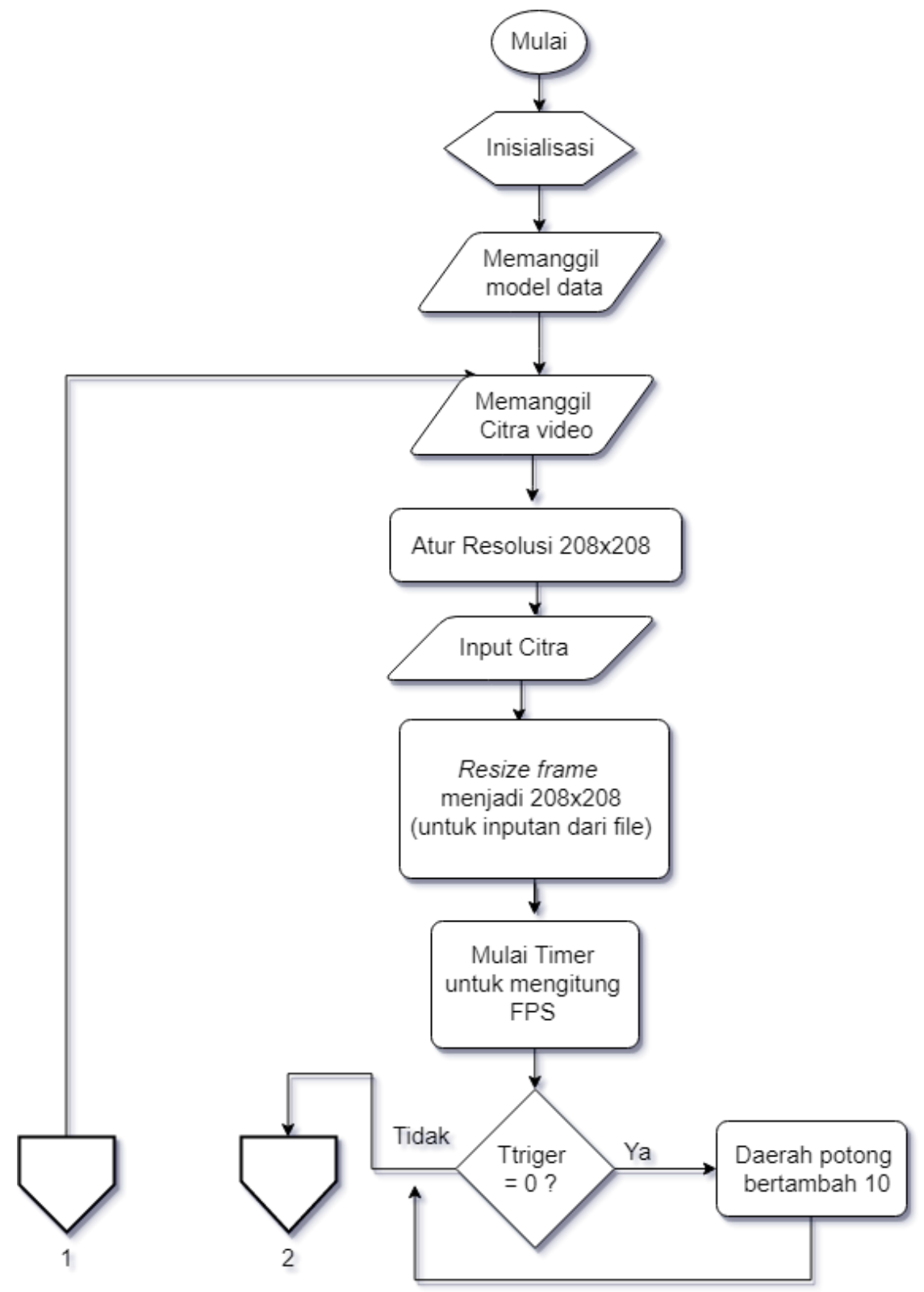



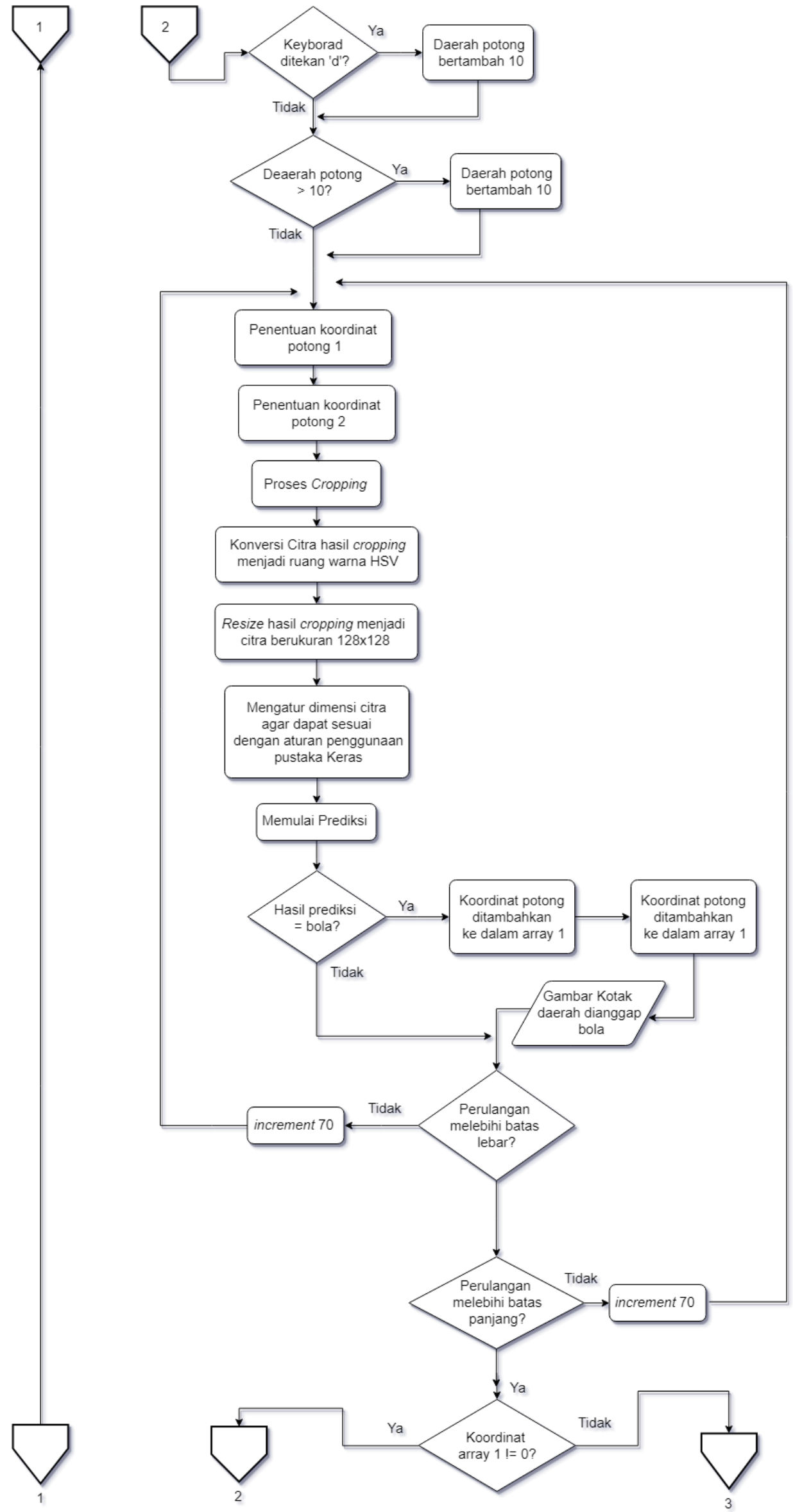

Buletin Ilmiah Sarjana Teknik Elektro, Vol. 2, No.1, April 2020: 40 - 50 


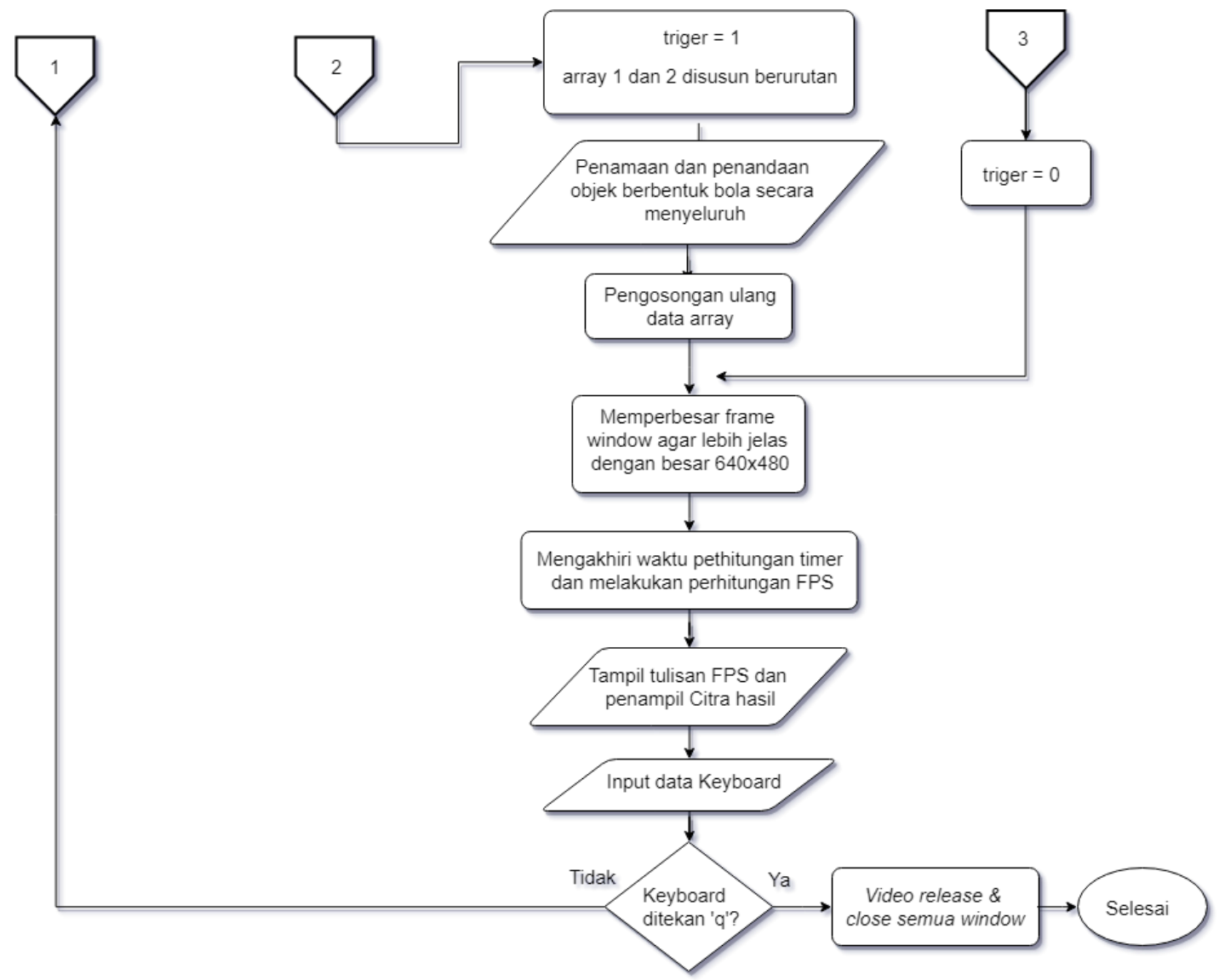

Gambar 7 Diagram alir program pendeteksian objek untuk verifikasi data

\section{HASIL DAN PEMBAHASAN}

Untuk mengetahui tingkat keberhasilan penerapan metode deep learning pada robot KRSBI Humanoid terlebih dahulu dilakukan pengujian pada robot dengan sistem yang telah dirancang. Pengujian pertama yaitu pengujian pada sistem yang dirancang penerapannya pada sistem visi. Pada sistem ini pengujian sistem terbagi menjadi dua tahap yaitu tahap pelatihan data dan tahap pengujian data. Pada tahap pelatihan data di dalamnya terdapat dua proses yaitu proses pengambilan data Citra dan proses pelatihan data dengan sistem yang telah dirancang. Tahap yang lain adalah tahap pengujian data yang mana di dalamnya terdapat proses verifikasi tingkat kebenaran sistem saat melakukan prediksi dari Citra yang telah disediakan.

\subsection{Pengujian pada Sistem Visi}

Pada bagian ini dilakukan proses pengambilan data Citra yang nantinya digunakan sebagai bahan pelatihan yang mana di dalam citra tersebut terdapat objek bola dengan berbagai kondisi. Kondisi tersebut di antaranya tempat pengambilan data, tingkat kecerahan ruangan, ada atau tidaknya latar belakang yang mencolok dan jarak bola terhadap kamera. Data tempat yang digunakan dapat dilihat pada tabel 2.

Tabel 2. Data tempat pengambilan citra

\begin{tabular}{ccccccc}
\hline \multirow{2}{*}{ No } & \multirow{2}{*}{ Tempat } & \multicolumn{3}{c}{ Kecerahan (lux) } & \multirow{2}{*}{ Latar identik } & \multirow{2}{*}{ Jarak bola } \\
\cline { 3 - 5 } & & Vertikal atas & Vertikal bawah & Horisontal & & \\
\hline 1 & Gedung Robotika & 143 & 27 & 93 & Ada & $30 \mathrm{~cm}, 50 \mathrm{~cm}, 1 \mathrm{~m}$ \\
\hline 2 & Gedung Robotika & 143 & 27 & 93 & Tidak ada & $30 \mathrm{~cm}$ \\
\hline 3 & Lab Komputer & 121 & 37 & 58 & Ada & $30 \mathrm{~cm}, 1 \mathrm{~m}$ \\
\hline 4 & Lab Komputer & 121 & 37 & 58 & Tidak ada & $30 \mathrm{~cm}$ \\
\hline 5 & Lab Komputer & 283 & 70 & 137 & Ada & $30 \mathrm{~cm}, 1 \mathrm{~m}$ \\
\hline 6 & Lab Komputer & 283 & 70 & 137 & Tidak ada & $30 \mathrm{~cm}, 1 \mathrm{~m}$ \\
\hline
\end{tabular}


Jumlah data yang diambil dengan program pengambil data adalah 1000 dan resolusi gambar 130x130 piksel. Data ini adalah data untuk menambah class pada sistem klasifikasi yang berisi objek-objek selain bola. Data tersebut diambil langsung dari kamera tanpa dilakukan konversi warna ulang oleh program dan langsung disimpan ke dalam komputer. Salah satu contoh dari pengambilan citra dengan kondisi-kondisi tersebut dapat dilihat pada Gambar 8.

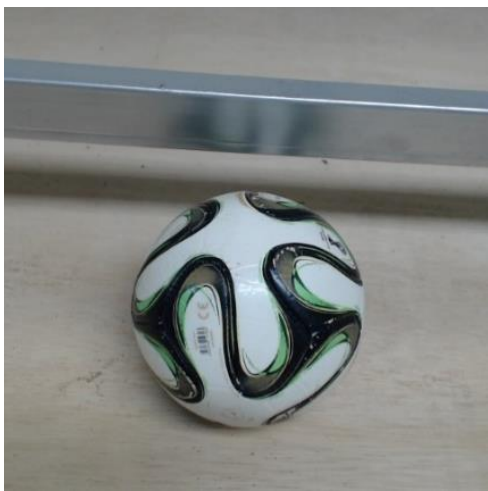

a) Kondisi kelima

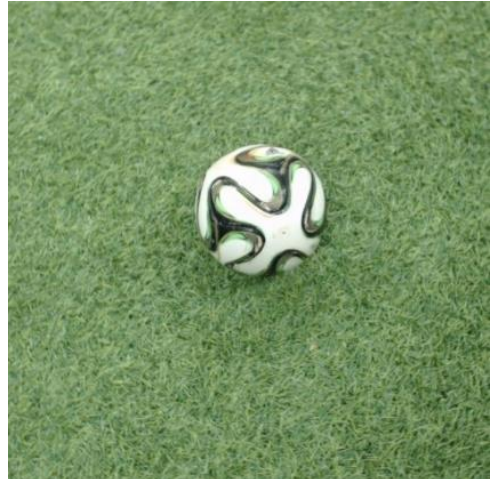

b) kondisi keenam

Gambar 8. Contoh citra yang diambil

\subsection{Pelatihan Data}

Percobaan pelatihan data yang dilakukan pada penelitian ini dilakukan dengan menggunakan variasi data yang berbeda yaitu sesuai dengan kondisi-kondisi yang telah disebutkan pada bagian pengambilan data dan sebagian kombinasi antara beberapa kondisi. Saat dilakukan pelatihan data jika dibuat dalam bentuk tabel hasil pelatihan-pelatihan tersebut dapat dilihat pada Tabel 3.

Tabel 3 Data percobaan pelatihan

\begin{tabular}{cccccc}
\hline Model & $\begin{array}{c}A c c \\
\text { Pelatihan }\end{array}$ & $\begin{array}{c}\text { Acc } \\
\text { Validasi }\end{array}$ & $\begin{array}{c}\text { Loss } \\
\text { Pelatihan }\end{array}$ & $\begin{array}{c}\text { Loss } \\
\text { Validasi }\end{array}$ & Penurunan \\
\hline 1 & $66 \%$ & $69 \%$ & $50 \%$ & $45 \%$ & 4 \\
\hline 2 & $81 \%$ & $73 \%$ & $40 \%$ & $40 \%$ & 4 \\
\hline 3 & $88 \%$ & $83 \%$ & $30 \%$ & $20 \%$ & 1 \\
\hline 4 & $91 \%$ & $99 \%$ & $2 \%$ & $2 \%$ & 2 \\
\hline 5 & $85 \%$ & $87 \%$ & $5 \%$ & $25 \%$ & 3 \\
\hline 6 & $65 \%$ & $80 \%$ & $4 \%$ & $46 \%$ & 5 \\
\hline 7 & $80 \%$ & $90 \%$ & $4 \%$ & $18 \%$ & 5 \\
\hline 8 & $87 \%$ & $98 \%$ & $35 \%$ & $4 \%$ & 1 \\
\hline 9 & $89 \%$ & $89 \%$ & $30 \%$ & $106 \%$ & 2 \\
\hline
\end{tabular}

Estimasi waktu dari pelatihan-pelatihan tersebut memiliki rentang waktu antara 8 sampai 10 detik per epoch dengan kecepatan 2 detik per step. Data-data tersebut walaupun beberapa memiliki akurasi yang cukup tinggi tetapi hanya berdasarkan data validasi citra yang didapat berbeda halnya dengan data yang didapat saat diujikan secara realtime dengan citra yang tentunya berbeda-beda.

\subsection{Verifikasi Data Citra}

Verifikasi data Citra di sini dilakukan untuk memastikan apakah data yang sudah dilakukan pelatihan memiliki tingkat akurasi yang benar-benar valid jika diberikan data secara real time dan dengan kondisikondisi yang telah ditentukan. verifikasi dilakukan dengan mengujikan tiap-tiap model yang telah dibuat. Verifikasi dilakukan dengan ketentuan berdasarkan model, resolusi dan jarak bola. Pada sistem verifikasi ini akan digunakan 3 jenis latar belakang seperti yang terlihat pada Gambar 9. 


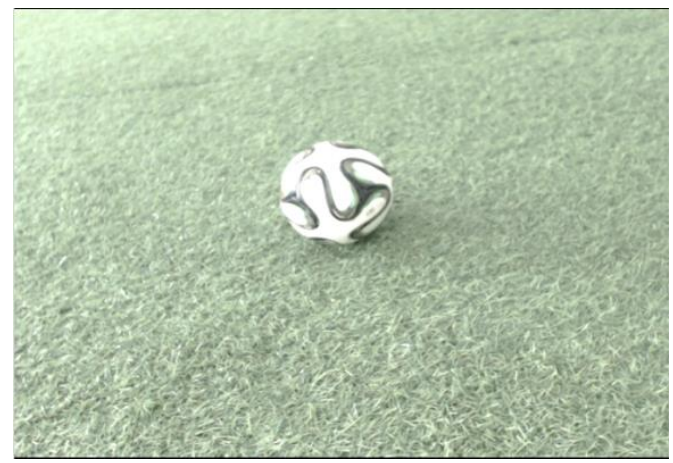

a) latar 1

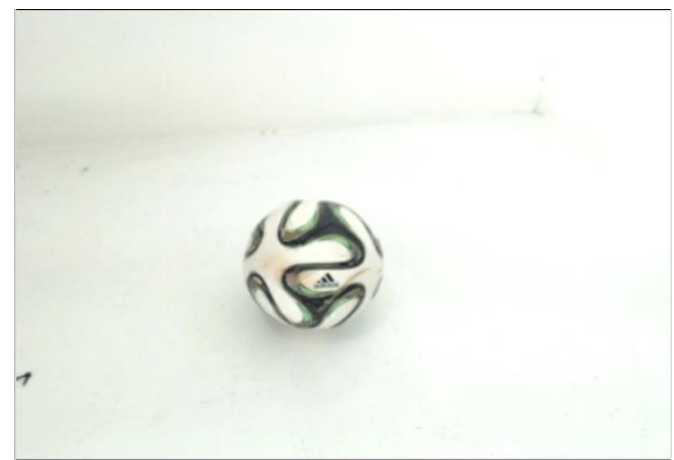

b) latar 2

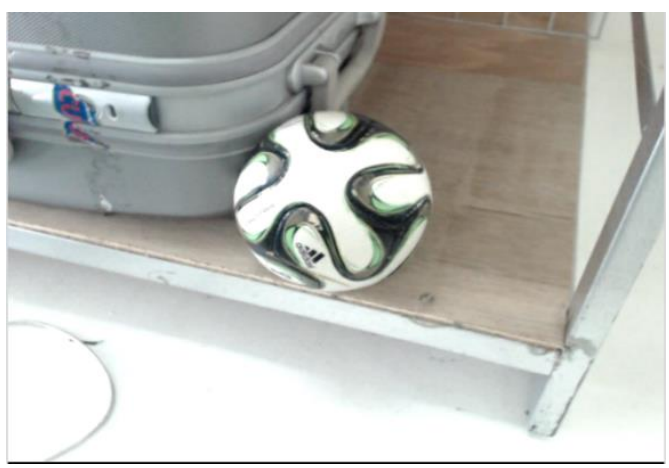

c) latar 3

Gambar 9 Contoh latar belakang Citra.

Dari percobaan yang telah dipaparkan tersebut dapat dibuatkan tabel hasil verifikasi data pelatihan dan dapat dilihat pada Tabel 4.

Tabel 4. Hasil akhir verifikasi data

\begin{tabular}{ccccc}
\hline Model & terdeteksi & $\begin{array}{c}\text { Latar saat } \\
\text { objek terdeteksi }\end{array}$ & $\begin{array}{c}\text { Resolusi saat } \\
\text { objek terdeteksi }\end{array}$ & FPS \\
\hline 1 & $\mathrm{~V}$ & 2 & 1 dan 2 & 2,10 dan 12 \\
\hline 2 & $\mathrm{X}$ & $\mathrm{x}$ & $\mathrm{x}$ & $\mathrm{x}$ \\
\hline 3 & $\mathrm{X}$ & $\mathrm{x}$ & $\mathrm{x}$ & $\mathrm{x}$ \\
\hline 4 & $\mathrm{~V}$ & 1 dan 2 & 2 & $\mathrm{x}$ \\
\hline 5 & $\mathrm{X}$ & $\mathrm{x}$ & $\mathrm{x}$ & 2 dan 13 \\
\hline 6 & $\mathrm{~V}$ & 2 & 1 dan 2 & 2,12 dan 13 \\
\hline 7 & $\mathrm{~V}$ & 1,2 dan 3 & 1 dan 2 & $\mathrm{x}$ \\
\hline 8 & $\mathrm{X}$ & $\mathrm{x}$ & $\mathrm{x}$ & 13 \\
\hline 9 & $\mathrm{~V}$ & 2 & 2 &
\end{tabular}

\section{KESIMPULAN}

Berdasarkan penelitian yang telah dilakukan yang mana perancangan sistem robot yang dipadukan dengan metode deep learning khususnya pada bagian sistem visi dan sistem berjalan telah dirancang dan dari penelitian tersebut dapat disimpulkan beberapa hal sebagai berikut. Pengembangan robot KRSBI Humanoid khususnya robot yang menggunakan platform Robotis OP3 dapat terus dikembangkan dan dikaji ulang terutama pada bagian-bagian yang berhubungan dengan fungsi dasar robot seperti berjalan, melihat dan menendang. Pendeteksian bola putih untuk proses bermain sepak bola pada robot dengan menerapkan metode deep learning dapat dilakukan dan memiliki persentase keberhasilan dan keakuratan yang cukup tinggi yaitu dari 9 model yang dibuat 5 di antaranya telah berhasil mengenali bola yang artinya 67\% model yang dirancang dapat mengenali objek dan juga kecepatan pengolahan gambar yang didapat adalah maksimal 13 FPS dengan

Penerapan Metode Deep Learning Convolution Neural Network pada Robot KRSBI Humanoid (Syahid Al Irfan1) 
catatan penggunaan perangkat keras yang harus memenuhi kriteria dan teknik pengambilan data yang perlu diperhatikan terutama data yang akan digunakan sebagai dasar validasi mode yang mana sedikit saja perbedaan yang dimasukkan maka akan berpengaruh fatal pada model yang dikembangkan.

\section{REFERENSI}

[1] T. M. Tsani, "Mesin Visi Pada Robot Sepak Bola R-SCUAD," Ahmad Dahlan, 2015.

[2] J. W. G. Putra, Pengenalan Konsep Pembelajaran Mesin dan Deep Learning, 1.1. 2018.

[3] E. M. KUSUMANINGTYAS, Ed., "Bab 8 Jaringan Saraf Tiruan (Neural networks)," in PENS : Kecerdasan Buatan, 2011.

[4] S. Yahya, "Fuzzy Logic, Neural Network, Genetic Algorithm Knowledge Based Expert System and Computational Intelligence," 2012.

[5] K. G. Kim, Book Review : Deep Learning. 2016.

[6] "Convolutional Neural Networks," Transactions of the Japanese Society for Artificial Intelligence, 2018. [Online]. Available: https://cs231n.github.io/convolutional-networks/.

[7] Y. Lecun, L. Eon Bottou, Y. Bengio, and P. Haaner, "Gradient-Based Learning Applied to Document Recognition RS-SVM Reduced-set support vector method. SDNN Space displacement neural network. SVM Support vector method. TDNN Time delay neural network. V-SVM Virtual support vector method," Proc. Ieee, no. November, pp. $1-46,1998$.

[8] Y. Kim, "Convolutional Neural Networks for Sentence Classification," Proc. 2014 Conf. Empir. Methods Nat. Lang. Process., pp. 1746-1751, 2014.

[9] A. Karpathy and T. Leung, "Karpathy Large-scale Video_Classification 2014 CVPR paper," pp. 10-20, 2018.

[10] R. D. Kusumanto, A. N. Tompunu, D. Wahyu, and S. Pambudi, "Klasifikasi Warna Menggunakan Pengolahan Model Warna HSV," vol. 2, no. 2, pp. 83-87, 2011.

[11] J. Redmon, S. Divvala, R. Girshick, and A. Farhadi, "You Only Look Once: Unified, Real-Time Object Detection," 2015.

[12] P. Taylor, I. Ha, Y. Tamura, and H. Asama, "Development of open platform humanoid robot," vol. 27, no. February, pp. 37-41, 2013.

[13] E. Rudiawan, R. Analia, D. S. P, and H. Soebakti, "The Deep learning Development for Real-Time Ball and Goal Detection of Barelang-FC," no. October, pp. 146-151, 2017. 